\title{
Epiphytic orchids Stanhopea tigrina and Prosthechea cochleata are differentially affected by drought in a subtropical cloud forest
}

\author{
C.I. GUEVARA-PÉREZ*, P. DELGADO-SÁNCHEZ**, J.A. TORRES-CASTILLO*, \\ J.D. FLORES-RIVAS ${ }^{* * *}$, G. MENDIETA-LEIVA ${ }^{\#}$, and E. DE LA ROSA-MANZANO ${ }^{*+}$ \\ Autonomous University of Tamaulipas, Institute of Applied Ecology, Gulf Division Av. 356, 87019 Victoria City, \\ Mexico* \\ Autonomous University of San Luis Potosi, Agronomy Faculty, 78321 Soledad de Graciano Sanchez, Mexico** \\ IPICYT, Environmental Sciences Division, 78216 San Luis Potosí, Mexico ${ }^{* * *}$ \\ Phillips University of Marburg, Department of Geography, AG Ecological Plant Geography, Deutschhausstr. 10, \\ D-26111 Marburg, Germany
}

\begin{abstract}
We investigated the physiological responses of two epiphytic orchids under three light regimes of 20, 50, and 70\% of total daily radiation under drought and rewatering conditions. Stanhopea tigrina was the one more affected because it exhibited strong photoinhibition and reduction of both electron transport rate and nocturnal acidity under drought and high radiation. However, this species maintained relatively high relative water content (RWC) values and underwent osmotic adjustment during the drought period and recovered photosynthetic variables during watered period. Prosthechea cochleata maintained similar water and photosynthetic responses to light conditions during the drought period and was more tolerant than S. tigrina. Principal component analysis provided evidence that water variables, such as RWC and succulence of both leaf and pseudobulb, were the most important variables for both species. Our results suggest that $S$. tigrina is more sensitive to drought than $P$. cochleata, and could be more affected by global warming.
\end{abstract}

Additional key words: chlorophyll fluorescence; Mexico; Orchidaceae; photosynthesis; water stress.

\section{Introduction}

Tropical mountain cloud forests (TMCF) are an important component of regional and global diversity and are one of the most vulnerable to climate change (Foster 2001, Burke 2003). Canopy plants such as epiphytes are conspicuous elements of tropical and subtropical ecosystems that contribute significantly to biodiversity and to carbon, nutrient, and water cycle (Nadkarni 1984, Benzing 1990). Despite high humidity in TMCF, epiphytes are exposed to dry microclimate due to intermittent water pulses, making water shortages the most limiting factor for their establishment and growth (Benzing 1990, Laube and Zotz 2003). Hence, these plants are considered drought susceptible, because they are not soil-rooted but obtain water and nutriments from the atmosphere, on which they are completely dependent (Zotz et al. 2010).

Precipitation has a positive effect on epiphyte distribution in tropical and subtropical ecosystems (Wolf and Flamenco 2003, Kreft et al. 2004), but it can be highly variable over space and time scales and thus affecting plant-water relationships (Goldsmith et al. 2012). For instance, in the tropical forest of 'El Triunfo' Reserve in Chiapas at Southern Mexico, annual precipitation can be up to 5,000 $\mathrm{mm}$ (Wolf and Flamenco 2003), while in the most humid forest in 'El Cielo' Biosphere Reserve (CBR) in Tamaulipas, in the north of the country, mean annual precipitation is $2,500 \mathrm{~mm}$ by year (González-Medrano 2005). Short rainless periods are common in TMCF as occurs in 'El Cielo' with 3-4 months of drought (Rzedowski 1996), when epiphytes experience an abrupt change in ecological conditions: solar radiation, temperature, and humidity. To deal with this variation, epiphytes draw on other sources of water such as fog or dew; it is known that fog contributes $20 \%$ or more of the total water input in cloud forests (Juvik and Ekern 1978, Stadtmüller 1987), supporting diversity in this ecosystem (Gradstein 2006). While dew is a water source that maintains water balance of epiphytic bromeliads during dry periods in a dry forest, it is not enough to contribute to growth (Andrade 2003).

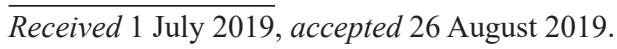

${ }^{+}$Corresponding author; e-mail: ermanzano@uat.edu.mx

Abbreviations: ETR - electron transport rate; $\mathrm{F}_{\mathrm{v}} / \mathrm{F}_{\mathrm{m}}-$ maximal quantum yield of PSII; NPQ - nonphotochemical quenching; RH - relative humidity; RWC - relative water content; T - temperature; TMCF - tropical mountain cloud forests; VPD - vapor pressure deficit; $\Delta \mathrm{H}^{+}$- nocturnal acidification; $\Psi_{\mathrm{s}}$ - osmotic potential.

Acknowledgements: We would like to thank Justo Sánchez for the valuable help in field work. C.I. Guevara-Pérez was recipient of a Ph.D. fellowship by National Council for Science and Technology, Mexico (304599). This study was financed by CONACYT CB-2015-01-259248. 
In this scenario, epiphytes may be vulnerable to climate change if it results in quicker onset and more severe and longer droughts (Coumou and Rahmstorf 2012, Trenberth et al. 2014), which would affect their physiology and survival and potentially alter their diversity (Nadkarni and Solano 2002, Ellis and Coppins 2007, Zotz et al. 2010).

Notwithstanding, light is another important abiotic condition that drives photosynthetic activity and growth. In the epiphytic habitat, plants are exposed directly or indirectly to solar radiation, which is linked to characteristics inherent to host trees, such as size, age, and deciduousness, among others (Benzing 1990, Esseen et al. 1996, Callaway et al. 2002, Lie et al. 2009). Full sunlight can be stressful for epiphytes, causing photoinhibition that results in damage to the photosynthetic apparatus, but low light also limits plant growth and survival (Sultan 2003, Walters 2005, Niinemets 2007). The susceptibility of plants to photoinhibition depends on the species and growth light environments (Anderson and Osmond 1987). It has been considered that shade plants or low-light-grown plants are more susceptible to photoinhibition than sun plants or highlight-grown plants (Osmond 1994). Hence, environmental conditions are determinant in understanding the ecological implications of tolerance to extremes, and particularly important to successful cultivations and preservation of wild orchid species (Lin and Hsu 2004).

Epiphytic species comprise more than $70 \%$ of the members of Orchidaceae (Silvera et al. 2009), one of the largest and most diverse families of flowering plants, comprising more than 25,000 species (Christenhusz and Byng 2016). Mexico possesses around 1,260 species of orchids (Hágsater et al. 2005) from which $40 \%$ are endemic, and $15 \%$ are categorized as endangered by Mexican environmental laws (SEMARNAT 2010). The epiphytic orchids, Stanhopea tigrina and Prosthechea cochleata, are considered as threatened and endangered species, respectively. The habitat of most orchids has been negatively impacted by anthropogenic activities (Soto-Arenas and Solano-Gómez 2007, Ray et al. 2018). However, a clear gap exists in its physiological requirements to contribute to their conservation; hence, it is necessary to accelerate conservation programs for these species. S. tigrina and P. cochleata colonize different environments, while the former inhabits the wet sites such as the tropical montane cloud forests in Mexico. The latter is distributed in broad habitat types, from wet to dry (Pridgeon et al. 2009) and might be more tolerant to environmental changes.

Epiphyte species respond differentially to abiotic conditions, e.g., the orchids Miltonia flavescens and M. spectabilis var. moreliana exhibit higher values of net photosynthetic rate, dark respiration, leaf transpiration rate, stomatal and intercellular conductance in response to atmospheric $\mathrm{CO}_{2}$ concentration rate at full sunlight than that at $25 \%$ shade, suggesting that these species appear to be adapted to conditions of high irradiance (Pires et al. 2012). In counterpart, the orchids Encyclia nematocaulon and Laelia rubescens strongly diminish their photosynthetic activity and water content because of high radiation during dry periods in a dry forest (de la Rosa-Manzano et al. 2014).
Hence, it is important to evaluate how plants respond to changes in water and light availability in order to understand the physiological requirements to establishment, growth, and survival of orchids, in particular, since they constitute one of the most endangered plant families in the world due to fragmentation, destruction, and illegal trading (Nash et al. 2003, Kull and Hutchings 2006, Phelps and Webb 2015).

Response to drought has been widely studied in epiphyte species from tropical forests (Griffiths and Smith 1983, Nowak and Martin 1997, Griffiths and Maxwell 1999, Reyes-García and Griffiths 2009, Zotz and Asshoff 2010, Reyes-García et al. 2012), but few studies have attempted to study responses to drought of epiphytic orchids in subtropical forest (Martin et al. 2004), where short rainless periods are common. Since epiphytic orchids inhabit a wide range of habitats, from very humid to seasonally dry (Dressler 1981), we studied, for the first time, tolerance to drought and light variability of the epiphytic orchids $P$. cochleata and $S$. tigrina from the TMCF in the 'El Cielo' to better understand their response to environmental conditions, with the aim of conserving them. TMCF represents less than $1 \%$ of the total area of the country and is one of the most threatened types of vegetation in Mexico (Challenger 1998, Luna-Vega et al. 2006). This forest is recognized as one of the ecosystems with the highest diversity per unit of area in Mexico; it presents high endemism of epiphytes and includes $10 \%$ of Mexican flora species (Rzedowski 1978, 1996; Luna-Vega 2000, Sánchez-González et al. 2008, Sánchez-Ramos et al. 2014). In this sense, we proposed the following questions. How do epiphyte orchids tolerate changes in water availability and light intensity? Does water deficit have a greater impact on photosynthetic light-utilization efficiency than excess light? Considering that $P$. cochleata is widely distributed in the 'El Cielo' reserve, we hypothesized that individuals of this species are more water conservative and maintain photosynthetic activity under drought and high-light intensity conditions than $S$. tigrina, which is restricted to cloud forest and could be more vulnerable. Because water is the most limiting abiotic factor for vascular epiphytes (Gentry and Dodson 1987, Zotz and Hietz 2001), we assumed that relative water content, succulence, and osmotic potential of any orchid organ, such as leaf, pseudobulb or root, would be more important than photosynthetic traits, such as nocturnal acidification, electron transport rate, maximum quantum yield of PSII, among others. Finally, we expected that rewatering favors orchid development, displaying a higher relative water content, succulence, and photosynthetic activity, than that of orchids under drought.

\section{Materials and methods}

Plant material: We selected the epiphytic orchids $S$. tigrina Bateman ex Lindl and P. cochleata (L.) W. E. Higgins due to high abundance in the CBR, although $S$. tigrina inhabits only the TMCF, and $P$. cochleata is also found in the tropical dry forest. S. tigrina is endemic to Mexico, while $P$. cochleata is distributed in Colombia, Venezuela, Central 
America, Antilles, Mexico, and United States (southern Florida) (Dressler 1981, Pridgeon 1981).

In the TMCF, we collected 15 mature healthy plants, comparable in their leaf number and pseudobulbs of each orchid species. The plants were put in a pot $\left(0.33 \mathrm{~m}^{3}\right)$ containing Quercus germana Schltdl. \& Cham. tree bark as substrate, the most common host tree for epiphytes in the TMCF (Castro-Huerta 2018). Plants were acclimated for $60 \mathrm{~d}$ under shade in a common garden in the ejido Alta Cima (where species are distributed). During this time, plants were watered twice a week.

Experimental design: After acclimation, five individuals of each orchid species were randomly transferred to one of three light treatments of photosynthetic photon flux density (PPFD). Artificial shading was created using nylon nets and the treatments were light intensities of $20 \%\left(6.84 \pm 0.57 \mathrm{~mol} \mathrm{~m}^{-2} \mathrm{~d}^{-1}\right), 50 \%(12.84 \pm 0.92 \mathrm{~mol}$ $\left.\mathrm{m}^{-2} \mathrm{~d}^{-1}\right)$, and $70 \%\left(18.35 \pm 1.27 \mathrm{~mol} \mathrm{~m}^{-2} \mathrm{~d}^{-1}\right)$ of PPFD. PPFD was measured with an S-LIA-M003 sensor (Onset Computer Corporation, USA) connected to data logger HOBO H21-002 (Onset Computer Corporation, USA). Air temperature and relative humidity in each treatment were measured with $\mathrm{HOBO}$ pro v2 Temp/RH U23-001 (Onset Computer Corporation, USA). Vapor pressure deficit (VPD) was calculated according to Jones (1992). Minimum data of microenvironment [(minimum temperature $\left(\mathrm{T}_{\min }\right)$, maximum relative humidity $\left(\mathrm{RH}_{\max }\right)$, minimum vapor pressure deficit $\left.\left(\mathrm{VPD}_{\min }\right)\right]$ were extracted from 3:00 to $6: 00 \mathrm{~h}$, and maximum data [maximum temperature $\left(\mathrm{T}_{\max }\right)$, minimum relative humidity $\left(\mathrm{RH}_{\min }\right)$, maximum vapor pressure deficit $\left(\mathrm{VPD}_{\max }\right)$ ] from 13:00 to 16:00 h. Reference sensors were placed outside of shade houses. All sensors registered data each hour during the entire experiment $(43 \mathrm{~d})$. Orchid plants were exposed to a drought period of $35 \mathrm{~d}$, when they reached low values of maximal quantum yield of PSII $\left(\mathrm{F}_{\mathrm{v}} / \mathrm{F}_{\mathrm{m}}\right)$. Plants were then watered and measured for $8 \mathrm{~d}$. Before the 35-d drought, we measured physiological traits, but they did not show such a strong decline as at $35 \mathrm{~d}$. During the drought period, we evaluated physiological traits that are frequently used to measure environmental stress and determine optimal growth conditions for plants (Lin and Hsu 2004).

Chlorophyll fluorescence: The parameters of chlorophyll (Chl) fluorescence were measured on fully expanded orchid leaves; quantum yield was measured at 9:00, 12:00, 15:00, and 18:00 h (here, we presented only data taken at 18:00 h). $F_{v} / F_{m}$ was measured before dawn $(6: 00 \mathrm{~h})$, and nonphotochemical quenching (NPQ) and electron transport rate (ETR) were assessed at the same hours as quantum yield; here, we presented maximum values of $\mathrm{NPQ}\left(\mathrm{NPQ}_{\max }\right)$ and ETR $\left(\mathrm{ETR}_{\max }\right)$, which correspond to 15:00 h. We used predawn maximum fluorescence $\left(\mathrm{F}_{\mathrm{m}}\right)$ to calculate NPQ. All calculations were performed as suggested by Maxwell and Johnson (2000).

Nocturnal acidification $\left(\mathbf{\Delta} \mathbf{H}^{+}\right)$was determined with samples $\left(5 \mathrm{~cm}^{2}\right)$ from fully expanded leaves collected at dusk and before dawn. After immediate storage in ethanol
$(60 \%, v / v)$, extraction and titration were performed in the laboratory following the protocol of Zotz and Andrade (1998).

Relative water content (RWC) is considered a better indicator of plant water status (Salehi-Lisar and Bakhshayeshan-Agdam 2016). For RWC, we collected leaf, pseudobulb, and root samples of two epiphytic orchids at predawn. Samples were placed in a plastic bag with moist filter paper in an insulated box with ice, transported to the laboratory to measure their fresh mass, placed in distilled water to obtain saturated mass, and then dried at $65^{\circ} \mathrm{C}$ for $24 \mathrm{~h}$ before measuring dry mass. RWC was calculated as: (fresh mass - dry mass)/ (saturated mass - dry mass) $\times 100$. For ssucculence, we considered the same samples used for RWC, but additionally we measured the total area for each sample. Succulence was calculated as: (fresh mass - dry mass)/ leaf area.

Osmotic potential $\left(\boldsymbol{\Psi}_{\mathrm{s}}\right)$ was measured for leaf and pseudobulb samples collected at predawn $(6: 00 \mathrm{~h})$. All samples were immediately frozen by immersion in liquid nitrogen and then stored at $5^{\circ} \mathrm{C}$ in the laboratory. Samples were then ground using a mortar, the tissue liquid was collected with filter paper discs, and osmotic pressure was determined using a vapor pressure osmometer (VAPRO 5520, Wescor, Logan, Utah, USA).

Data analysis: The experiment was conducted in a completely randomized design, with a $3 \times 2$ factorial arrangement, three light levels $(20,50$, and $70 \%$ of PPFD) and two species ( $P$. cochleata and $S$. tigrina) with five replicates during drought and rewatering period. Physiological traits were compared using a two-way analysis of variance (ANOVA) followed by the Tukey's test. Normality was checked using the Kolmogorov and Smirnov's test. We used a Kruskal-Wallis test when variables were not normally distributed. In order to determine if water variables are more important than photosynthetic traits, we ran a principal components analysis (PCA, function prcomp) to evaluate the physiological characteristics of the species studied under three PPFD treatments. For PCA, we used the variables leaf and pseudobulb RWC, leaf and pseudobulb succulence, $\mathrm{F}_{\mathrm{v}} / \mathrm{F}_{\mathrm{m}}$, leaf and pseudobulb $\Psi_{\mathrm{s}}, \Delta \mathrm{H}^{+}$, yield and $\mathrm{ETR}_{\max }$ of plants under drought period to understand which variables varied along the axis of the microclimatic gradient; data were centered and scaled. A multivariate analysis of variance (MANOVA) was performed to determine the effect of species and light treatments on the most important variables from the PCA (RWC, succulence, and osmotic potential, all of leaves, and nocturnal acidification). Values of $P \leq 0.05$ were accepted as significant. All analyses were carried out with the statistical software $R$ version 3.3.3 (R Core Team 2018).

\section{Results}

Microenvironment conditions, such as temperature (T), relative humidity $(\mathrm{RH})$, and vapor pressure deficit (VPD), 
presented slight changes among light treatments during $35 \mathrm{~d}$ of drought (Table 1). $\mathrm{T}_{\text {mean }}$ was similar between the 20 and $50 \%$ PPFD treatments and increased by $1{ }^{\circ} \mathrm{C}$ at $70 \%$ PPFD. $\mathrm{T}_{\min }$ showed values similar to $\mathrm{T}_{\text {mean }}$, which was around $14^{\circ} \mathrm{C}$ for the 20 and $50 \%$ PPFD treatments, and slightly increased with the $70 \%$ PPFD. $\mathrm{T}_{\max }$ was similar among light treatments $\left(\mathrm{ca} .28^{\circ} \mathrm{C}\right) . \mathrm{RH}_{\text {mean }}$ and $\mathrm{RH}_{\max }$ were higher at $20 \%$ PPFD than that at the other PPFD treatments. $\mathrm{RH}_{\min }$ decreased nearly by $53 \%$, relative to $\mathrm{RH}_{\max }$, in each of the light treatments. $\mathrm{VPD}_{\text {mean }}$ showed higher values at $70 \%$ PPFD treatment and lower at 20\% PPFD treatment. $\mathrm{VPD}_{\max }$ and $\mathrm{VPD}_{\min }$ increased with light treatment intensities, reaching values around 2.12 and $0.17 \mathrm{kPa}$, respectively (Table 1 ). During the rewatering period, $\mathrm{T}_{\text {mean }}$ increased $1{ }^{\circ} \mathrm{C}$ compared to the drought period, but $\mathrm{T}_{\max }$ increased to $3^{\circ} \mathrm{C}$ at $70 \%$ PPFD. $\mathrm{T}_{\min }$ was similar to the drought period under the three light treatments. $\mathrm{RH}_{\text {mean }}$, $\mathrm{RH}_{\max }$, and $\mathrm{RH}_{\min }$ diminished around $10 \%$ in the three light treatments compared to the drought period. Values of
$\mathrm{VPD}_{\text {mean }}(c a .1 .22 \mathrm{kPa}), \mathrm{VPD}_{\text {max }}(c a .2 .73 \mathrm{kPa})$, and $\mathrm{VPD}_{\text {min }}$ (ca. $0.2 \mathrm{kPa}$ ) were higher than that of the drought period in the three light treatments.

Drought period: Drought and light intensities significantly influenced water relations and photosynthetic activity of the orchids $P$. cochleata and S. tigrina. Interaction between species and light levels affected nocturnal acidification $\left(\Delta \mathrm{H}^{+}\right)$(Fig. 1A). P. cochleata presented a higher mean value of $\Delta \mathrm{H}^{+}\left[27.64 \pm 2.01 \mu \mathrm{mol}\left(\mathrm{H}^{+}\right) \mathrm{g}^{-1}(\mathrm{FM})\right]$ than that of S. tigrina $\left[16.14 \pm 2.01 \mu \mathrm{mol}\left(\mathrm{H}^{+}\right) \mathrm{g}^{-1}(\mathrm{FM})\right]$. Differences in $\Delta \mathrm{H}^{+}$between species were notable, especially under 50 and $70 \%$ of PPFD. No differences in $\Delta \mathrm{H}^{+}$were observed for $P$. cochleata under the three light levels, while the $\Delta \mathrm{H}^{+}$of $S$. tigrina decreased under the 50 and $70 \%$ PPFD treatments compared to the $20 \%$ PPFD treatment. Plants of both epiphytic orchids showed low values of $\mathrm{F}_{\mathrm{v}} / \mathrm{F}_{\mathrm{m}}$ $(<0.6)$ under the three light levels but they were notably lower in S. tigrina at the 70\% PPFD treatment (Fig. 1B).

Table 1. Microclimatic variables in three light treatments (20,50, and 70\% PPFD) during drought and rewatering period. Data of drought period represent register of $35 \mathrm{~d}$, and those of rewatering period are register of $8 \mathrm{~d}$. Data are mean $\pm \mathrm{SE}$. $\mathrm{T}_{\text {mean }}-$ mean temperature; $\mathrm{T}_{\max }$ - maximum temperature; $\mathrm{T}_{\min }$ - minimum temperature; $\mathrm{HR}_{\text {mean }}$ - mean relative humidity; $\mathrm{HR}_{\max }$ - maximum relative humidity; $\mathrm{HR}_{\min }$ - minimum relative humidity; $\mathrm{VPD}_{\text {mean }}$ - mean vapor pressure deficit; $\mathrm{VPD}_{\max }$ - maximum vapor pressure deficit; VPD $\mathrm{Vin}_{\min }-$ minimum vapor pressure deficit.

\begin{tabular}{|c|c|c|c|}
\hline & Light level [\%] & Drought period & Rewatering period \\
\hline \multirow{3}{*}{$\mathrm{T}_{\text {mean }}\left[{ }^{\circ} \mathrm{C}\right]$} & 20 & $20.70 \pm 0.50$ & $21.37 \pm 0.79$ \\
\hline & 50 & $20.77 \pm 0.50$ & $21.38 \pm 0.88$ \\
\hline & 70 & $21.13 \pm 0.51$ & $21.58 \pm 0.78$ \\
\hline \multirow[t]{3}{*}{$\mathrm{T}_{\max }\left[{ }^{\circ} \mathrm{C}\right]$} & 20 & $28.49 \pm 0.99$ & $30.78 \pm 0.78$ \\
\hline & 50 & $28.20 \pm 0.97$ & $29.64 \pm 0.98$ \\
\hline & 70 & $28.50 \pm 0.99$ & $31.51 \pm 0.95$ \\
\hline \multirow[t]{3}{*}{$\mathrm{T}_{\min }\left[{ }^{\circ} \mathrm{C}\right]$} & 20 & $14.65 \pm 0.47$ & $14.40 \pm 1.37$ \\
\hline & 50 & $14.68 \pm 0.46$ & $14.82 \pm 1.47$ \\
\hline & 70 & $15.07 \pm 0.46$ & $14.92 \pm 1.29$ \\
\hline \multirow[t]{3}{*}{$\mathrm{RH}_{\text {mean }}[\%]$} & 20 & $74.61 \pm 1.44$ & $64.89 \pm 4.86$ \\
\hline & 50 & $73.71 \pm 1.41$ & $63.03 \pm 4.71$ \\
\hline & 70 & $72.63 \pm 1.33$ & $61.86 \pm 5.20$ \\
\hline \multirow[t]{3}{*}{$\mathrm{RH}_{\max }[\%]$} & 20 & $91.16 \pm 1.31$ & $87.70 \pm 5.31$ \\
\hline & 50 & $90.08 \pm 1.28$ & $84.16 \pm 5.65$ \\
\hline & 70 & $86.12 \pm 2.73$ & $84.15 \pm 4.98$ \\
\hline \multirow[t]{3}{*}{$\mathrm{RH}_{\min }[\%]$} & 20 & $50.45 \pm 2.44$ & $37.50 \pm 4.97$ \\
\hline & 50 & $50.66 \pm 2.34$ & $37.01 \pm 5.54$ \\
\hline & 70 & $49.11 \pm 2.68$ & $37.55 \pm 4.63$ \\
\hline \multirow[t]{3}{*}{$\mathrm{VPD}_{\text {mean }}[\mathrm{kPa}]$} & 20 & $0.88 \pm 0.07$ & $1.17 \pm 0.10$ \\
\hline & 50 & $0.90 \pm 0.06$ & $1.23 \pm 0.11$ \\
\hline & 70 & $0.94 \pm 0.07$ & $1.21 \pm 0.11$ \\
\hline \multirow[t]{3}{*}{$\mathrm{VPD}_{\max }[\mathrm{kPa}]$} & 20 & $2.08 \pm 0.18$ & $2.79 \pm 0.17$ \\
\hline & 50 & $2.11 \pm 0.17$ & $2.65 \pm 0.19$ \\
\hline & 70 & $2.17 \pm 0.18$ & $2.75 \pm 0.17$ \\
\hline \multirow[t]{3}{*}{$\mathrm{VPD}_{\min }[\mathrm{kPa}]$} & 20 & $0.15 \pm 0.02$ & $0.20 \pm 0.09$ \\
\hline & 50 & $0.17 \pm 0.02$ & $0.26 \pm 0.09$ \\
\hline & 70 & $0.20 \pm 0.02$ & $0.26 \pm 0.08$ \\
\hline
\end{tabular}




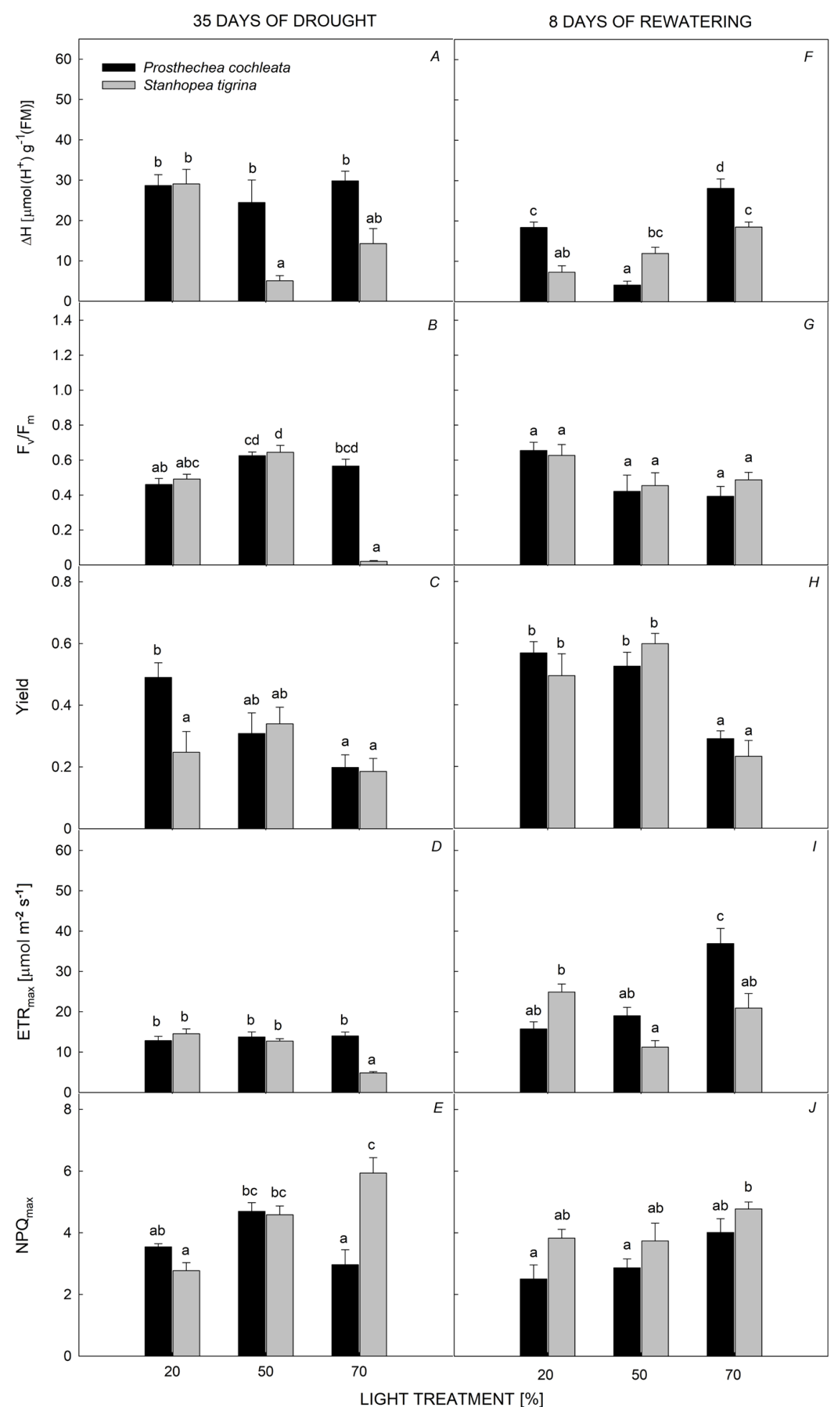

Fig. 1. Nocturnal acidification $\left(\Delta \mathrm{H}^{+}\right)$, maximal quantum yield of PSII $\left(\mathrm{F}_{\mathrm{v}} / \mathrm{F}_{\mathrm{m}}\right)$, yield, maximum electron transport rate $\left(\mathrm{ETR}_{\max }\right)$, and maximum nonphotochemical quenching $\left(\mathrm{NPQ}_{\max }\right)$ of Prosthechea cochleata and Stanhopea tigrina at three light treatments during drought and rewatering period. Different letters above bars indicate significant differences, $P<0.05$. Data are mean $\pm \mathrm{SE}, n=5$.
$P$. cochleata plants had slightly higher values of $\mathrm{F}_{\mathrm{v}} / \mathrm{F}_{\mathrm{m}}$ $(0.63 \pm 0.02)$ under $50 \%$ PPFD than those under 20 and $70 \%$ PPFD (0.46 \pm 0.03 and $0.57 \pm 0.04$, respectively; Fig. $1 B)$. There was a decrease in yield $(0.20 \pm 0.09)$ for $P$. cochleata under $70 \%$ PPFD compared to values under $20 \%$ of PPFD treatment $(0.49 \pm 0.11$; Fig. $1 C)$. No differences in yield were registered for $S$. tigrina under three light intensities (Fig. 1C).
P. cochleata plants showed a smaller increase in

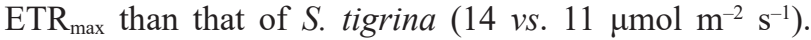
Although orchids received different light intensities, no differences were observed in $\mathrm{ETR}_{\max }$ for $P$. cochleata under the three levels of light (Fig. 1D). While $S$. tigrina had a significant decrease in $\mathrm{ETR}_{\max }$ under $70 \%$ PPFD compared to plants under 20 and 50\% PPFD (Fig. $1 D$ ). In addition, there was a significant effect of the interaction 
light levels and species on $\mathrm{NPQ}_{\max } ; S$. tigrina reached higher mean values of $\mathrm{NPQ}_{\max }(4.43 \pm 0.20)$ than that of $P$. cochleata $(3.73 \pm 0.20)$. Comparisons among light levels showed that $S$. tigrina registered higher values of $\mathrm{NPQ}_{\max }$ at $70 \%$ PPFD than either the 20 or the $50 \%$ PPFD, while $P$. cochleata slightly increased $\mathrm{NPQ}_{\max }$ with $50 \%$ PPFD compared to the $70 \%$ PPFD (Fig. $1 E$ ).

Both species showed higher values of RWC in leaves followed by pseudobulbs and roots, and different trends among orchid organs were observed. Interaction of light levels with species affected the RWC of leaves and pseudobulbs. $P$. cochleata had a higher leaf $(69.6 \pm 2.55 \%$, Fig. $2 A)$ and pseudobulbs $(54.0 \pm 1.32 \%$, Fig. $2 B)$ RWC than that of $S$. tigrina $(60.14 \pm 1.41$ and $45.7 \pm 1.97 \%$, respectively). However, we did not find differences for leaf RWC and pseudobulb RWC between light levels for each species (Fig. 2A,B). Root RWC significantly differed between species, but there was no effect of light levels (Fig. 2C).

Pseudobulbs were the most important organ for succulence in both species, followed by leaves and roots. Succulence of pseudobulbs and leaves was influenced by the interaction of light levels and species (Fig. 3); $P$. cochleata had higher mean values of succulence than that of $S$. tigrina in both organs (Fig. $3 A, B$ ). Differences in succulence of pseudobulbs and leaves between light levels were not found for $P$. cochleata, while $S$. tigrina showed higher values of succulence in both pseudobulbs and leaves under the 50 and $70 \%$ PPFD, compared to individuals under the 20\% PPFD (Fig. $3 A, B$ ). The lowest values of succulence [around $16 \mathrm{~mol}\left(\mathrm{H}_{2} \mathrm{O}\right) \mathrm{m}^{-2}$ ] of both orchids were found in roots, compared to other orchid organs. Succulence of roots exhibited significant differences between light levels for both species (Fig. 3C), but no differences were found between species (Fig. 3C).

Osmotic potential $\left(\Psi_{\mathrm{s}}\right)$ of leaves and pseudobulbs was significantly different between species (Fig. 4A,B). S. tigrina showed lower leaf mean $\Psi_{\mathrm{s}}$ values $(-0.71 \pm 0.02 \mathrm{MPa})$ than that of $P$. cochleata $(-0.45 \pm 0.02 \mathrm{MPa})$, but it was inverse for pseudobulbs. Light levels had no effect on leaf $\Psi_{\mathrm{s}}$ of either species (Fig. $4 A$ ).

The PCA showed that components 1,2, and 3 accounted for $70.2 \%$ of the total variation (Table 2, Fig. 5). Component 1 explained $36.5 \%$ of the variation and was represented by positive loadings of leaf and pseudobulb succulence and RWC, followed by yield and $\mathrm{F}_{\mathrm{v}} / \mathrm{F}_{\mathrm{m}}$ (Table 2, Fig. 5). Component 2 explained $19.1 \%$ of the variation and was represented by negative loadings of leaf and pseudobulb $\Psi_{\mathrm{s}}$ (Table 2, Fig. 5). Component 3, which explained 14.7\% of the variation, had positive loading for $\mathrm{ETR}_{\max }$ and negative for $\Delta \mathrm{H}^{+}$(Table 2, Fig. 5). The MANOVA indicated a significant effect of interaction between species and light treatments on RWC, leaf $\Psi_{\mathrm{s}}$ and succulence, and $\Delta \mathrm{H}^{+}$ (Table 3). In post-hoc $A N O V A \mathrm{~s}$, there was a significant orchid species effect on all variables, with exception of nocturnal acidification, which was different only between light treatments.

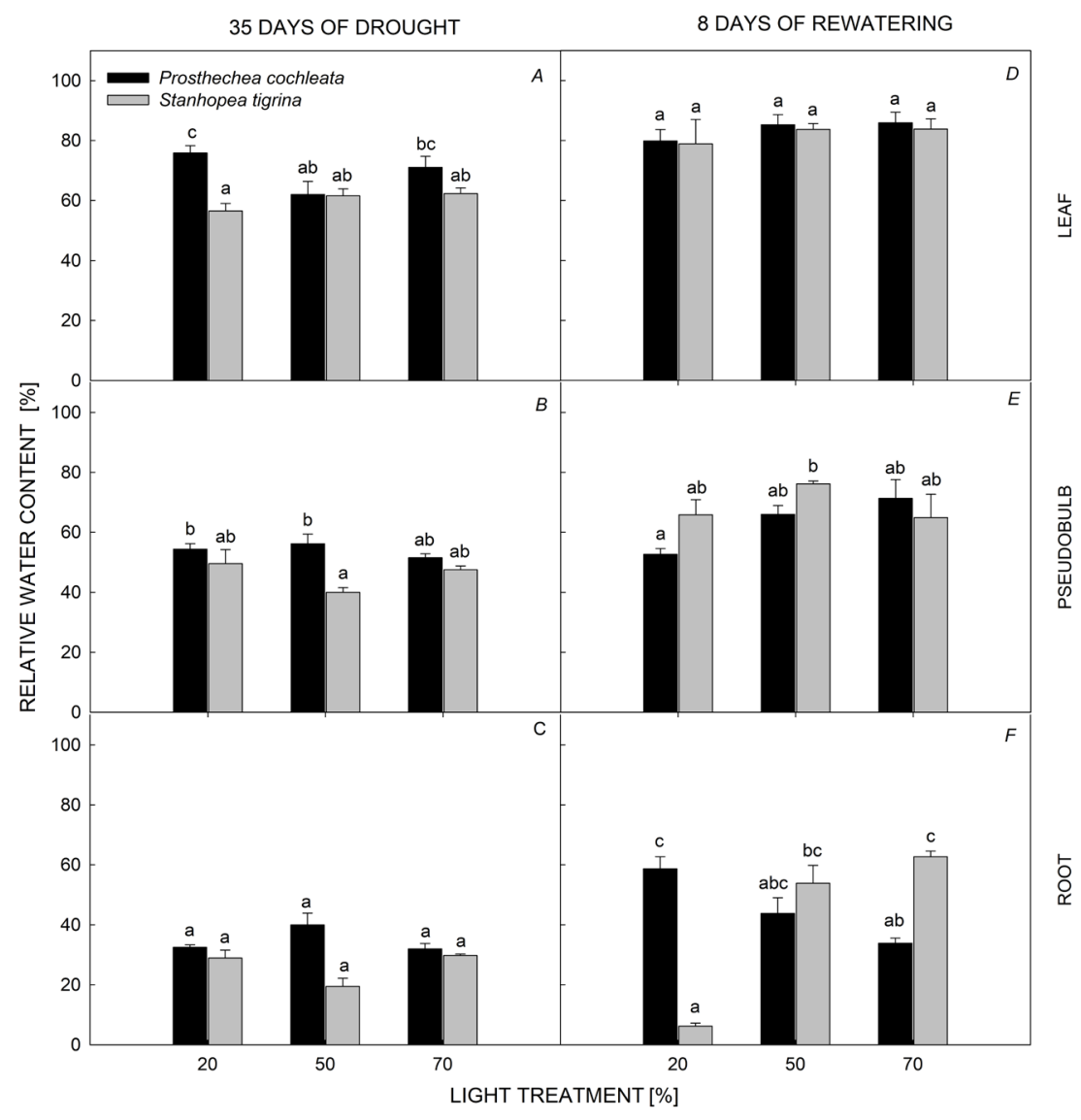

Fig. 2. Relative water content of Prosthechea cochleata and Stanhopea tigrina at level of root, pseudobulb, and leaf at three light treatments during drought and rewatering period. Different letters above bars indicate significant differences, $P<0.05$. Data are mean $\pm \mathrm{SE}$, $n=5$. 


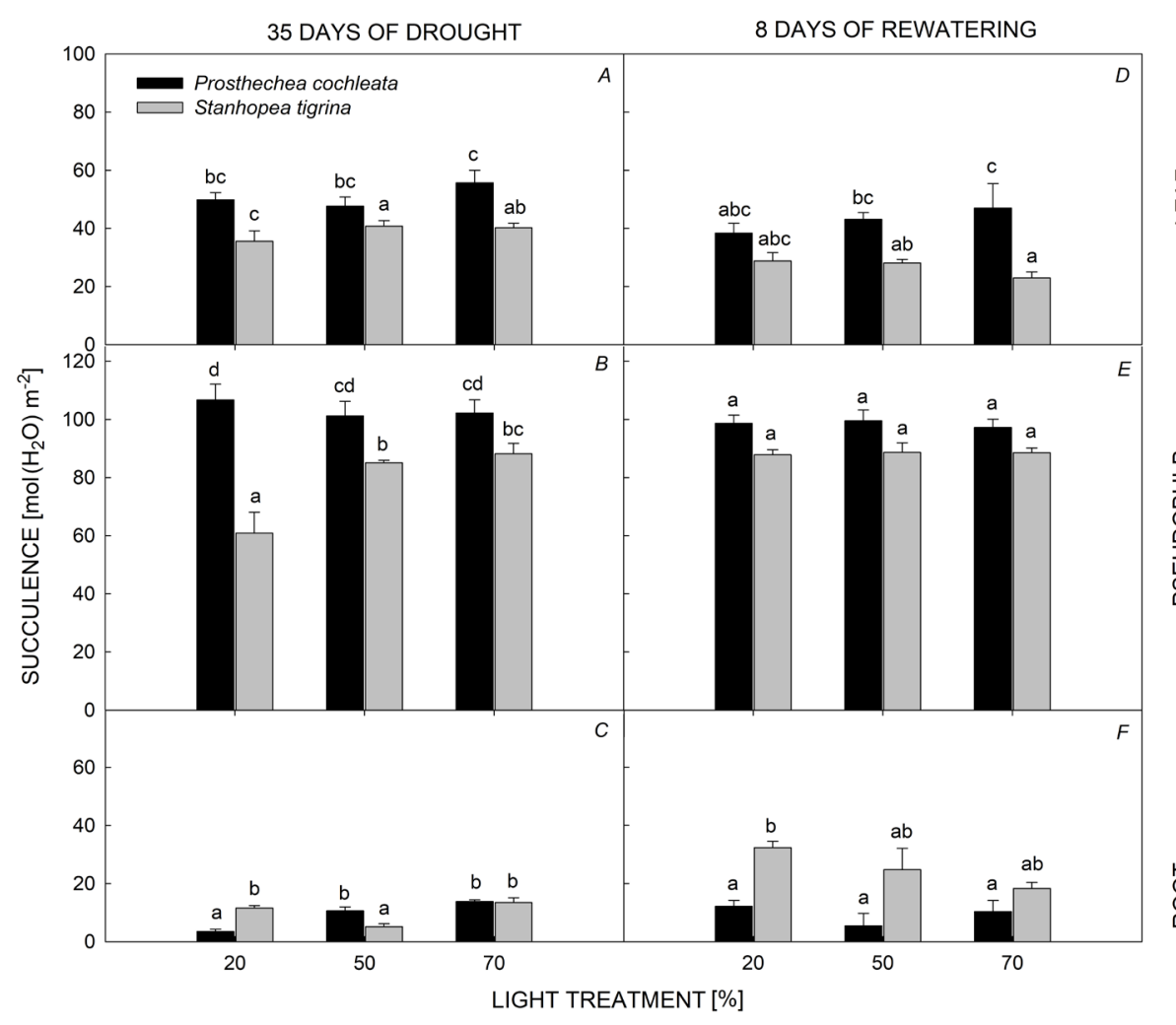

峞

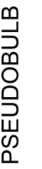

Fig. 3. Succulence of Prosthechea cochleata and Stanhopea tigrina at level of root, pseudobulb, and leaf at three light treatments during drought $\circ$ and rewatering period. Different letters above bars indicate significant differences, $P<0.05$. Data are mean \pm $\mathrm{SE}, n=5$.

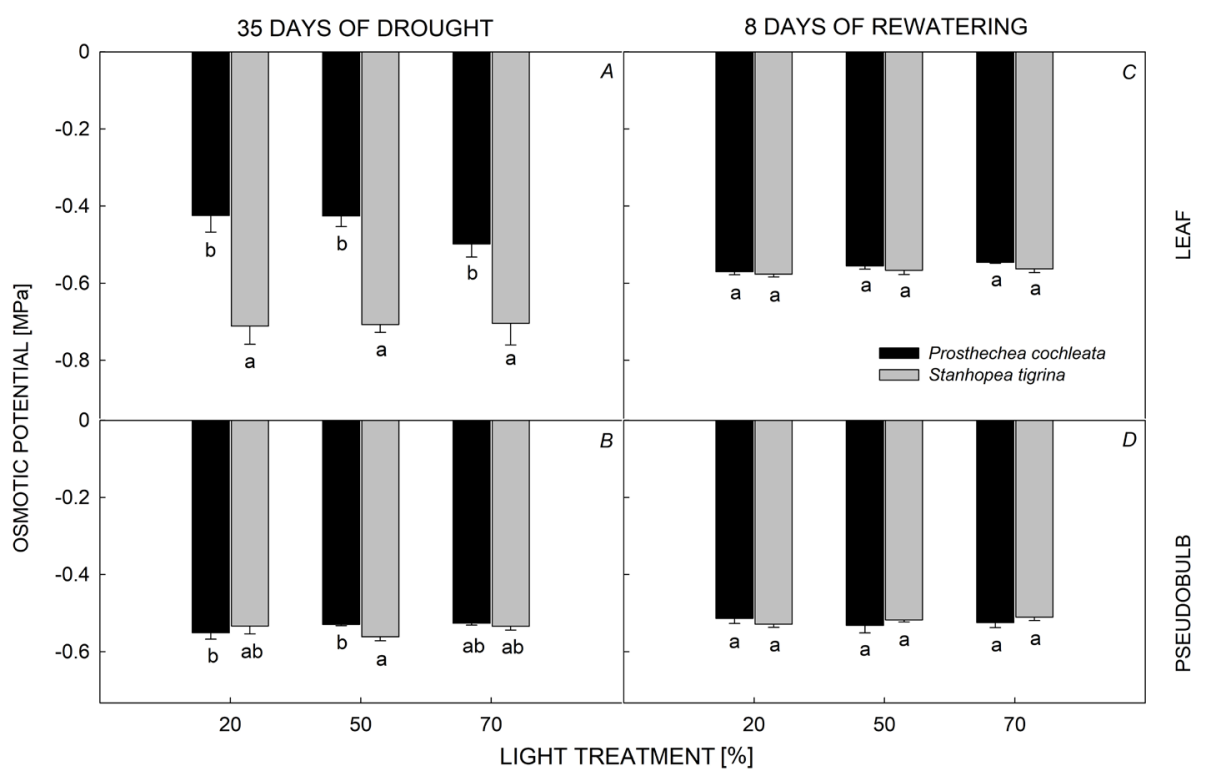

岀

Fig. 4. Osmotic potential of Prosthechea cochleata and Stanhopea tigrina at level of pseudobulb and leaf at three light treatments during drought and rewatering period. Different letters mean significant differences, $P<0.05$. Data are mean \pm SE, $n=5$.
Rewatering period: After plants were watered, they recovered their photosynthetic activity and water status. $\Delta \mathrm{H}^{+}$was affected by the interaction of light levels and species (Fig. 1). P. cochleata exhibited significantly higher values of $\Delta \mathrm{H}^{+}\left[16.81 \pm 0.91 \mu \mathrm{mol}\left(\mathrm{H}^{+}\right) \mathrm{g}^{-1}(\mathrm{FM})\right]$ than $S$. tigrina $\left[12.56 \pm 0.91 \mu \mathrm{mol}\left(\mathrm{H}^{+}\right) \mathrm{g}^{-1}(\mathrm{FM})\right]$, although these values were lower than those during the drought period (Fig. 1A-E). Both orchid species presented differences in $\Delta \mathrm{H}^{+}$between light levels (Fig. $1 F$ ); $\Delta \mathrm{H}^{+}$significantly diminished under $50 \%$ PPFD and increased under $70 \%$ of PPFD (Fig. 1F). Neither the interactions between light levels and species (Fig. 1G) nor the species (Fig. 1G) had an effect on $\mathrm{F}_{\mathrm{v}} / \mathrm{F}_{\mathrm{m}}$. This variable only was different between light levels, which was higher under the 20\% PPFD treatment and lower under the 50 and 70\% PPFD treatments. Although S. tigrina had the lowest values during drought period under 70\% PPFD, plants recovered to $\sim 0.5$ yield (Fig. $1 H$ ).

ETR $_{\max }$ was affected by the interaction of light treatments and species (Fig. 1I). At the species level, P. cochleata had 
Table 2. Principal components (PC) obtained from physiological characteristics of Stanhopea tigrina and Prosthechea cochleata grown under 20, 50, and 70\% of PPFD intensities during drought period. RWC - relative water content; $\Psi_{\mathrm{s}}-$ osmotic potential; $\Delta \mathrm{H}^{+}-$nocturnal acidification; $\mathrm{ETR}_{\max }-$ maximum electron transport rate; $\mathrm{F}_{\mathrm{v}} / \mathrm{F}_{\mathrm{m}}-$ maximal quantum yield of PSII; yield - quantum yield.

\begin{tabular}{|c|c|c|c|}
\hline Variables & PC1 & PC2 & PC3 \\
\hline RWC of leaves [\%] & 0.3617 & - & - \\
\hline RWC of pseudobulbs [\%] & 0.3966 & - & - \\
\hline Succulence of leaves $\left[\mathrm{mol}\left(\mathrm{H}_{2} \mathrm{O}\right) \mathrm{m}^{-2}\right]$ & 0.4498 & - & - \\
\hline Succulence of pseudobulbs $\left[\mathrm{mol}\left(\mathrm{H}_{2} \mathrm{O}\right) \mathrm{m}^{-2}\right]$ & 0.3183 & - & - \\
\hline$\Psi_{\mathrm{s}}$ of leaves $[\mathrm{MPa}]$ & - & -0.5878 & - \\
\hline$\Psi_{\mathrm{s}}$ of pseudobulbs $[\mathrm{MPa}]$ & - & -0.5279 & - \\
\hline$\Delta \mathrm{H}^{+}\left[\mu \mathrm{mol}\left(\mathrm{H}^{+}\right) \mathrm{g}^{-1}(\mathrm{FM})\right]$ & - & - & -0.3452 \\
\hline $\mathrm{ETR}_{\max }\left[\mu \mathrm{mol} \mathrm{m}{ }^{-2} \mathrm{~s}^{-1}\right]$ & - & - & 0.5222 \\
\hline $\mathrm{F}_{\mathrm{v}} / \mathrm{F}_{\mathrm{m}}$ & 0.3493 & - & - \\
\hline Yield & 0.3740 & - & - \\
\hline Proportion of variance [\%] & 36.45 & 19.05 & 14.66 \\
\hline Cumulative proportion [\%] & 36.45 & 55.51 & 70.17 \\
\hline
\end{tabular}

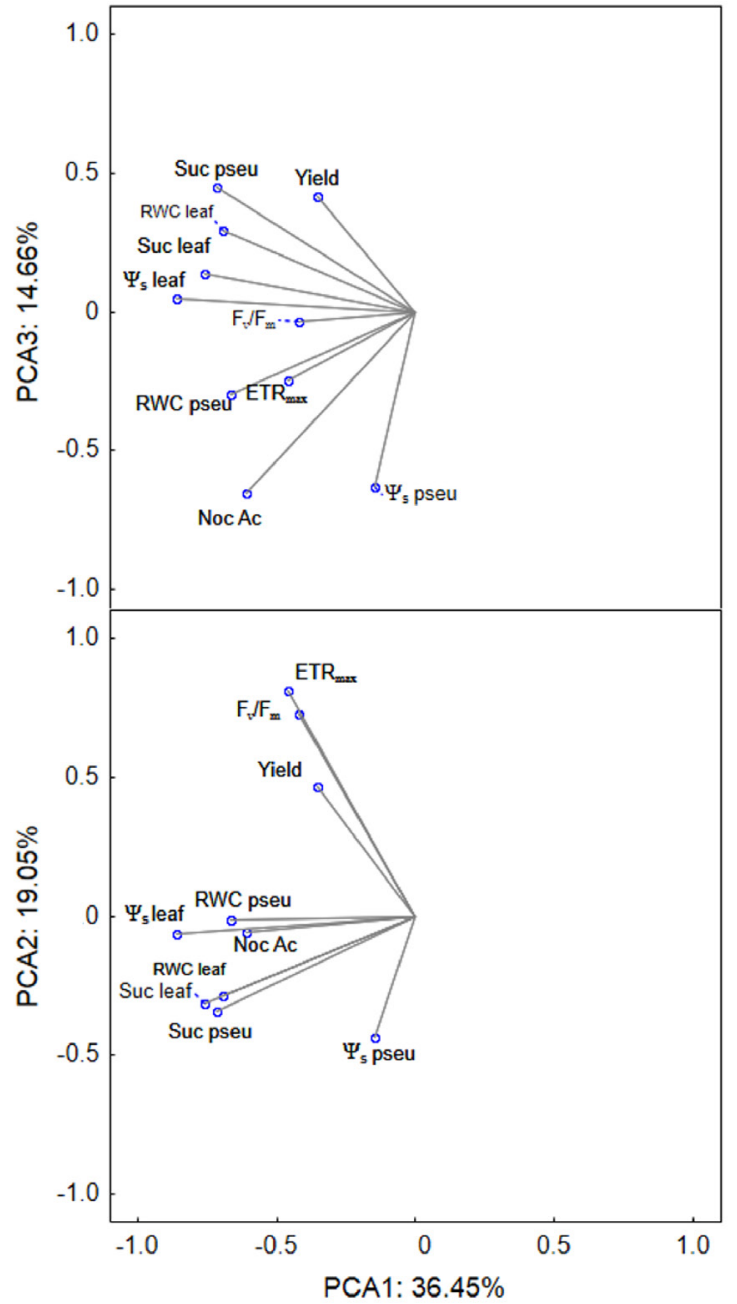

Fig. 5. Principal components analysis (PCA) ordination diagram displaying correlations between physiological characteristics in epiphytes Prosthechea cochleata and Stanhopea tigrina under 20,50 , and $70 \%$ of PPFD treatment during drought period. Physiological variables are listed in Table 2. higher values of $\mathrm{ETR}_{\max }$ than that of S. tigrina (Fig. 1I), and values were remarkable under the 70\% PPFD. On the other hand, $\mathrm{NPQ}_{\max }$ was different between light levels (Fig. $1 J$ ) and species (Fig. 1J). S. tigrina had significantly higher $\mathrm{NPQ}_{\max }(4.11 \pm 0.23)$ than that of $P$. cochleata $(3.13 \pm 0.23)$.

Different orchid organs recovered RWC, relative to the drought period. Orchids did not have significant differences in leaf RWC $(\sim 80 \%)$ between light treatments (Fig. $1 D)$. Leaves recovered $\sim 20 \%$ RWC relative to the drought period. Pseudobulbs RWC showed significant differences only between light levels (Fig. $1 E$ ), with no differences between species (Fig. 1E); pseudobulbs recovered $\sim 15 \%$ of the RWC lost in the drought period. Orchid roots showed a clear increase of RWC under the three light levels (Fig. $1 F)$; P. cochleata significantly increased the RWC of roots under the $20 \%$ PPFD $(59 \pm 8 \%)$, compared to the $50 \%(44 \pm 10 \%)$ and $70 \%$ PPFD (34 $\pm 3 \%$; Fig. $1 F)$. Roots of $S$. tigrina exhibited the lowest values of RWC under $20 \%$ PPFD $(6 \pm 2 \%)$ compared with the 50\% $(54 \pm 11 \%)$ and $70 \%$ PPFD $(63 \pm 3 \%$; Fig. $1 F)$.

Neither the interaction of light levels and species nor light levels caused differences in leaf, pseudobulb or root succulence (Fig. 2D-F). P. cochleata presented higher values of succulence than that of $S$. tigrina, in both organs, leaves $\left[42.81 \pm 2.37\right.$ vs. $\left.26.72 \pm 2.37 \mathrm{~mol}\left(\mathrm{H}_{2} \mathrm{O}\right) \mathrm{m}^{-2}\right]$ and pseudobulbs $\left[98.47 \pm 1.60\right.$ vs. $88.32 \pm 1.60 \mathrm{~mol}\left(\mathrm{H}_{2} \mathrm{O}\right)$ $\mathrm{m}^{-2}$. At the root level, succulence response was reversed between species, $S$. tigrina showed higher values than that of $P$. cochleata $\left[25.13 \pm 2.35\right.$ vs. $9.32 \pm 2.35 \mathrm{~mol}\left(\mathrm{H}_{2} \mathrm{O}\right) \mathrm{m}^{-2}$, Fig. $2 F$ ]. Neither light levels nor species had an effect on $\Psi_{\mathrm{s}}$ of leaves and pseudobulbs (Fig. $4 D-E$ ); mean values of both species were around $-0.56 \pm 0.01$ and $0-0.52 \pm$ $0.01 \mathrm{MPa}$, respectively.

\section{Discussion}

Epiphytic orchids responded differentially to drought under different light intensities. $P$. cochleata was more tolerant to temporary drought than $S$. tigrina in agreement 
Table 3. Multivariate analysis of variance to estimate the effect of the light and species in physiological traits (relative water content, succulence, and osmotic potential, all of leaves, and nocturnal acidification) of two epiphytic orchids during drought period. Significance codes: $0^{\text {‘***’ }}, 0.05^{\text {‘**’ }}$.

\begin{tabular}{lrrl}
\hline Sources of variation & Df & \multicolumn{1}{l}{$F$} & $P$ \\
\hline Species & 1 & 50.302 & $0.0000481^{* * *}$ \\
Light & 1 & 2.668 & $0.0579819^{* *}$ \\
Species $\times$ Light & 1 & 6.755 & $0.0009498^{* * *}$ \\
Residuals & 26 & - & - \\
\hline
\end{tabular}

with our hypothesis. Despite the increase in NPQ, the interaction of drought and the highest light intensity resulted in a stressful environment for $S$. tigrina photosynthesis, as suggested by the decreases in ETR, $\mathrm{F}_{\mathrm{v}} / \mathrm{F}_{\mathrm{m}}$, yield, and nocturnal acidification. S. tigrina is well adapted to intermediate light in the middle zone of the host Q. germana in 'El Cielo' (Castro-Huerta 2018) but deciduousness of this host during short dry periods can negatively affect their photosynthesis. While $P$. cochleata inhabits more open micro-habitats, such as the tropical dry forest, where this species has the capacity to tolerate both drought and high light intensity as was observed by higher values of ETR, $F_{v} / F_{m}$, yield, and nocturnal acidification with no differences between light levels. Our results are in agreement with those found for six orchid species of Singapore, where water deficit has a greater impact on photosynthetic light-utilization efficiency than excess light (Tay et al. 2015). Other studies indicate that some epiphytic orchids can acclimatize under 100 and $75 \%$ of the total irradiance, showing high mean values of net photosynthetic rate (Boardman 1977, Pires et al. 2012). Even for the epiphytic orchid Cypripedium guttatum, a level of $45 \%$ irradiance is optimal for photosynthesis (Zhang et al. 2003, 2007).

Low values of $\mathrm{F}_{\mathrm{v}} / \mathrm{F}_{\mathrm{m}}$ of $S$. tigrina under the $70 \%$ PPFD treatment during the drought period was related to an increase in both light and temperature (Table 1). Leaves exposed to higher light intensity can exacerbate photoinhibition (Mulkey and Pearcy 1992) and even cause greater vapor pressure deficits leading to reduction of quantum yield (Cornic and Briantais 1991, Crain and Tremblay 2017). The $\mathrm{F}_{\mathrm{v}} / \mathrm{F}_{\mathrm{m}}$ seems to diminish when thermal dissipation is not enough to protect the PSII against excessive light (Tognetti et al. 1998a,b) as occurred in $S$. tigrina, while $P$. cochleata showed an inverse pattern - a lower dissipation and increased $\mathrm{F}_{\mathrm{v}} / \mathrm{F}_{\mathrm{m}}$. $S$. tigrina could perhaps be considered a shade species, which are known to have reduced photoprotective systems (e.g., xanthophyll pigments) as compared to sun plants (Demmig-Adams et al. 1995, Demmig-Adams and Adams 2000, de la Rosa-Manzano et al. 2015). When energy dissipation in the antenna of PSII is low, a more active photosynthetic electron transport may help to mitigate the effect of photodamage in shade-grown plants (Kitao et al. 2000). However, in our study electron transport of $S$. tigrina was also low and the $70 \%$ PPFD treatment was likely excessive, evidenced by very low yield values at 18:00 h, enhancing risk of photodamage (DemmigAdams and Adams 2000). High risk of photoinhibition under strong radiation, even in sun-grown individuals, could result from the well-established trade-off between shade tolerance and low growth rate under high irradiance (Grubb et al. 1996). Even though S. tigrina plants exhibited strong photoinhibition under $70 \%$ PPFD, they were able to recover their photosynthetic activity during the rewatering period at $8 \mathrm{~d}$, evidenced by value increases of NPQ, ETR, $\mathrm{F}_{\mathrm{v}} / \mathrm{F}_{\mathrm{m}}$, nocturnal acidification, and yield. Our results are similar to Cui et al. (2004) who found that rewatering resulted in sudden revival from the stress in Doritaenopsis orchid. Our findings are consistent with the significant role that electron transport capacity and energy dissipation play a role in ameliorating photodamage for shade-grown plants (Kitao et al. 2001).

Another plausible explanation for the remarkable differences in $\mathrm{F}_{\mathrm{v}} / \mathrm{F}_{\mathrm{m}}$ between orchid species under higher light intensity is the differences in exposed leaf area. Supporting its shade distribution, $S$. tigrina has a larger exposed leaf area $(23-45 \mathrm{~cm}$ length $\times 5-13 \mathrm{~cm}$ width $)$ than that of $P$. cochleata $(15-28 \mathrm{~cm}$ length $\times 1.5-3.5 \mathrm{~cm}$ width $)$, which is more vulnerable to photoinhibition than those grown in full sun, because shade leaves have a higher light-capturing capacity as a result of larger antenna size of PSII, and lower rates of light-saturated photosynthesis due to lower amounts of photosynthetic enzymes (Björkman 1981, Anderson and Osmond 1987, Osmond 1994).

Lower values of nocturnal acidification of S. tigrina under high light intensity during the drought period are in agreement with decreased functioning of their photosynthetic apparatus. This species was not able to use high light intensities, unlike $P$. cochleata, which improved nocturnal environmental conditions, such as low VPD $(\sim 0.17 \mathrm{kPa})$ to maintain higher nocturnal acidification, although similar values under the three light conditions without water were exhibited. Values of nocturnal acidification of both orchid species are comparable to epiphyte bromeliads from dry forest during the dry season in the field (Reyes-García et al. 2008) and under drought in greenhouse conditions (Reyes-García et al. 2012). It is well known that nocturnal acidification depends directly on PPFD preceding day (Andrade et al. 2007) and PPFD values around 13 and $18 \mathrm{~mol} \mathrm{~m}^{-2} \mathrm{~d}^{-1}$ resulted in a negative effect on photosynthesis of orchids from TMCF. The time $(35 \mathrm{~d})$ of drought imposed on both orchids was longer (especially for S. tigrina) than that imposed on epiphytic orchids from tropical dry forest (15 d, de la Rosa-Manzano et al. 2014), which has harsher environmental conditions, such as higher nocturnal and diurnal VPD (0.6 and $5.0 \mathrm{kPa}$, respectively), resulting in a deep decrease of photosynthetic activity. In our study, $P$. cochleata maintained similar nocturnal acidification under the three light treatments during the drought period, suggesting that low stomata aperture could be parallel to recycling of respiratory $\mathrm{CO}_{2}$ via CAM (Lüttge 2002), such as in Tillandsia ionantha in which $22 \%$ of the malic acid accumulated was derived from internal $\mathrm{CO}_{2}$ after $50 \mathrm{~d}$ without water (Nowak and Martin 1997). Similar response 
was found in other species of orchids (Lüttge 1987, Griffiths et al. 1989) and the Tillandsia genus (Griffiths et al. 1986, 1989; Martin and Adams 1987, Loeschen et al. 1993). Presumably recycling respiratory $\mathrm{CO}_{2}$ constitutes an adaptation that contributes to the apparent tolerance of orchids to long periods of drought; however, it is necessary realize measurements in the field.

The decrease of leaf osmotic potential observed in both epiphytic orchids after $35 \mathrm{~d}$ is a characteristic response of many CAM plants to drought (Griffiths et al. 1986, Lüttge 1987, Smith 1989, Martin 1994). The lower leaf osmotic potential of $S$. tigrina (around $-0.70 \mathrm{MPa}$ ) was in agreement with the decline in leaf RWC and the increase in nocturnal acidification, which had lower values under the $70 \%$ PPFD treatment. More negative leaf osmotic potential is a common adaptation of plants to drought (Lambers et al. 1998) to maintain nonzero cell turgor pressure and allows plants to harvest water (Martin et al. 2004). Hence, differences in osmotic potential between pseudobulbs and leaves of $S$. tigrina may allow translocating water from high concentration sites to low concentration sites. During the drought period, osmotic potential for the epiphytic orchids increases $S$. tigrina resistance to drought, by osmotic adjustment, a mechanism that helps plants acclimatize to dry conditions (Sanders and Arndt 2012), and not a simple concentration of solutes due to tissue desiccation. Similar phenomena occur in other epiphytes species that accumulate osmolytes (Griffiths et al. 1986, Smith 1989, Martin 1994, Stiles and Martin 1996, Nowak and Martin 1997). However, it is necessary to study the role of solutes, such as glycine betaine or proline, in epiphytes because their content varies among species (Ashraf and Bashir 2003).

Apparently, $P$. cochleata plants are highly resistant to drought because leaf osmotic potential remained similar during both the drought and rewatering periods, and leaf relative water content declined by only $20 \%$ at $35 \mathrm{~d}$ without water. In contrast, the RWC of the orchid Eria velutina decreased from $98 \%$ to a minimum of $65 \%$ at $20 \mathrm{~d}$ of drought in the field in southeastern Australia (Sinclair 1983a). Also, it can be compared with declines in relative water content of $70 \%$ for leaves of the fern Pyrrosia angustata (Sinclair 1983a,b). Leaf relative water content was relatively high in epiphytic orchids during the drought period, supporting the idea that perhaps stomata were slightly closed to conserve water and diminish nocturnal $\mathrm{CO}_{2}$ uptake and probably to recycle internal $\mathrm{CO}_{2}(\mathrm{Goh}$ and Kluge 1989). P. cochleata was more water conservative than $S$. tigrina, even at $70 \%$ PPFD, which could represent an advantage for dealing with long drought periods in the TMCF.

Relative water content of leaf, pseudobulb, and root of each orchid studied remained constant among light treatments during the drought period, and the principal components analysis suggests that responses in term of water related traits, such as RWC and succulence, were more evident during the drought period, supporting our prediction. $P$. cochleata appeared to be relatively more resistant to water depletion than $S$. tigrina because $P$. cochleata leaf, pseudobulb, and root RWC decreased by around $15 \%$, while $S$. tigrina RWC decreased by $30 \%$ during the drought period, reinforcing the idea that $S$. tigrina was more vulnerable to drought. Apparently, pseudobulbs of both species were more susceptible to drought than leaves because they lost more water (Fig. 1). Stancato et al. (2001) also found that the decrease in RWC of droughtstressed plants $(45 \mathrm{~d})$ was greater in pseudobulbs than that in leaves of the epiphytic orchid Cattleya forbesii Lind., indicating that pseudobulbs facilitate a slow reduction of RWC in the leaf. Even though the epiphytic orchids were under stress for $35 \mathrm{~d}$, this did not represent severe hydric stress for plants, because leaf RWC was above $40 \%$ (Cockerham and Leinauer 2011). Leaf RWC was around $70 \%$ for $P$. cochleata and $60 \%$ for $S$. tigrina, suggesting that, among other things, high nocturnal humidity $(\sim 90 \%)$ and low nocturnal VPD $(\sim 0.17 \mathrm{kPa})$ may have contributed to water conservation during the drought period. This was similar to what occurred in Cattleya orchid plants after three weeks of stress: they maintained leaf RWC above $70 \%$, because the pseudobulbs were capable of delaying excessive water loss during drought. Pseudobulbs consist of water-storing tissue that orchids use to adjust to water deficit (Zheng et al. 1992, Pires et al. 2012). Water lost from leaves through transpiration may be rapidly replaced by water previously stored in the pseudobulbs, which perform as water suppliers, as likely occurred with the epiphytic orchids under stress conditions in this study, evidencing that pseudobulbs are effective reservoirs for buffering plant stress (Goh and Kluge 1989, Yang et al. 2016).

Succulence is an adaptive characteristic by which epiphytes store water in large, water-rich parenchyma cells. Notably, P. cochleata was more succulent than $S$. tigrina considering the three organs. Root was the least succulent, similar to findings for the orchid Epidedrum secundum under field conditions (Moreira et al. 2009). Less succulence in roots was related to presence of an exoderm with dead cells and thick suberized walls that prevent apoplastic transport (Fahn 1990). Roots of S. tigrina clearly increase succulence during the rewatering period, while those of $P$. cochleata maintained similar succulence through the drought period. Orchids are characterized by the presence of velamen roots, capable of absorbing and storing water (Benzing et al. 1982, Benzing 1987). $S$. tigrina could be more efficient than $P$. cochleata, because it recovered around $35 \%$ of their root RWC.

We conclude that the two epiphytic orchids were differentially affected by interaction of drought and light, reinforcing the view of separation of niches in the CBR, $S$. tigrina is more shade restricted in the TMCF, while $P$. cochleata colonizes more open sites including the tropical dry forest. $P$. cochleata was able to conserve more water; its RWC remained around 70\% under the three PPFD treatments. Also, it is probably more wateruse efficient than $S$. tigrina, giving it an advantage in subsequent stressful environmental conditions, such as high temperature and water deficit in TMCF (Nadkarni and Solano 2002) and may be more resilient than drought-resistant bromeliads (Wolf and Flamenco 2006, Rosado-Calderón et al. 2018). S. tigrina appeared to be more vulnerable to drought under high light; however, this species makes an osmotic adjustment to adapt to 
stress conditions, where high relative water content and succulence of pseudobulbs play an important role in their water balance. Also, for both species, favorable nocturnal microenvironment with maximum relative humidity and minimum VPD might help to mitigate the drought period. Nevertheless, further studies focused on responses to drought in the field would be useful for conservation of epiphytic orchids.

\section{References}

Anderson J.M., Osmond C.B.: Shade-sun responses: Compromises between acclimation and photoinhibition. In: Kyle D.J., Osmond C.B.,Arntzen C.J.(ed.): Photoinhibition. Pp. 1-38. Elsevier Science Publishers, Amsterdam 1987.

Andrade J.L.: Dew deposition on epiphytic bromeliad leaves: An important event in a Mexican tropical dry deciduous forest. - J. Trop. Ecol. 19: 479-488, 2003.

Andrade J.L., de la Barrera E., Reyes-García C. et al.: [Crassulacean acid metabolism: diversity, environmental physiology and productivity.] - Bull. Bot. Soc. Mex. 81: 3750, 2007. [In Spanish]

Ashraf M., Bashir A.: Salt stress induced changes in some organic metabolites and ionic relations in nodules and other plant parts of two crop legumes differing in salt tolerance. Flora 198: 486-498, 2003.

Benzing D.H., Ott D.W., Friedman W.E.: Roots of Sobralia macrantha (Orchidaceae): Structure and function of the velamen-exodermis complex. - Am. J. Bot. 69: 608-614, 1982.

Benzing D.H.: Vascular epiphytism: Taxonomic participation and adaptive diversity. - Ann. Mo. Bot. Gard. 74: 183-204, 1987.

Benzing D.H.: Vascular Epiphytes. General Biology and Related Biota. Pp. 354. Cambridge University Press, Cambridge 1990.

Björkman O.: Responses to different quantum flux densities. In: Lange O.L., Nobel P.S., Osmond C.B., Ziegler H. (ed.): Physiological Plant Ecology I. Responses to the Physical Environment. Pp. 57-107. Springer Verlag, Berlin 1981.

Benzing D.H., Ott D.W., Friedman W.E.: Roots of Sobralia macrantha (Orchidaceae): structure and function of the velamen-exodermis complex. - Am. J. Bot. 69: 608-614, 1982.

Boardman N.K.: Comparative photosynthesis of sun and shade plants. - Ann. Rev. Plant Physio. 28: 355-377, 1977.

Burke A.: Inselbergs in a changing world - global trends. Divers. Distrib. 9: 375-383, 2003.

Callaway R.M., Reinhart K.O., Moore G.W. et al.: Epiphyte host preferences and host traits: Mechanisms for species specific interactions. - Oecologia 132: 221-230, 2002

Castro-Huerta O.G.: [Epiphytic orchids from tropical montane cloud forest of 'El Cielo' Biosphere Reserve, Tamaulipas, Mexico: horizontal and vertical distribution in Quercus germana Schltdl. \& Cham.] Bachelor Thesis. Technological Institute of Cd. Victoria, Tamaulipas, Mexico 2018.

Challenger A.: [Use and conservation of terrestrial ecosystems of Mexico: past, present and future.] Pp. 848. CONABIO Institute of Biology, UNAM and Agrupación Sierra Madre, SC, Mexico 1998.

Christenhusz M.J.M., Byng J.W.: The number of known plant species in the world and its annual increase. - Phytotaxa 261: 201-217, 2016.

Cockerham S.T., Leinauer B.: Turfgrass Water Conservation. Pp. 165. University of California, Agriculture and Natural
Resources, Davis 2011.

Cornic G., Briantais J.M.: Partitioning of photosynthetic electron flow between $\mathrm{CO}_{2}$ and $\mathrm{O}_{2}$ reduction in a $\mathrm{C}_{3}$ leaf (Phaseolus vulgaris L.) at different $\mathrm{CO}_{2}$ concentrations and during drought stress. - Planta 183: 178-184, 1991.

Coumou D., Rahmstorf S.: A decade of weather extremes. - Nat. Clim. Change 2: 491-496, 2012.

Crain B.J., Tremblay R.L.: Hot and bothered: Changes in microclimate alter chlorophyll fluorescence measures and increase stress levels in tropical epiphytic orchids. - Int. J. Plant Sci. 178: 503-511, 2017.

Cui Y.Y., Pandey D.M., Hahn E.J. et al.: Effect of drought on physiological aspects of Crassulacean acid metabolism in Doritaenopsis. - Plant Sci. 167: 1219-1226, 2004.

de la Rosa-Manzano E., Andrade J.L., García-Mendoza E. et al.: Photoprotection related to xanthophyll cycle pigments in epiphytic orchids acclimated at different light microenvironments in two tropical dry forests of the Yucatan Peninsula, Mexico. - Planta 242: 1425-1438, 2015.

de la Rosa-Manzano E., Andrade J.L., Zotz G. et al.: Physiological responses to drought of five epiphytic orchid species from two tropical dry forests of the Yucatan Peninsula. - Bot. Sci. 92: 607-616, 2014.

Demmig-Adams B.,Adams III W.W., Logan B.A., VerhoevenA.S. Xanthophyll cycle-dependent energy dissipation and flexible photosystem II efficiency in plants acclimated to light stress. - Aust. J. Plant Physiol. 22: 249-260, 1995.

Demmig-Adams B., Adams III W.W.: Photosynthesis Harvesting sunlight safely. - Nature 403: 373-374, 2000.

Dressler R.: The Orchids. Natural History and Classification. Pp. 332. Harvard University Press, Cambridge-London 1981.

Ellis C.J., Coppins B.J.: Changing climate and historic-woodland structure interact to control species diversity of the 'Lobarion' epiphyte community in Scotland. - J. Veg. Sci. 18: 725-734, 2007.

Esseen P.A., Renhorn K.E., Petersson R.B.: Epiphytic lichen biomass in managed and old-growth boreal forests: Effect of branch quality. - Ecol. Appl. 6: 228-238, 1996.

Fahn A.: Plant Anatomy. Pp. 588. Pergamon, Oxford 1990.

Foster P.: The potential negative impacts of global climate change on tropical montane cloud forests. - Earth-Sci. Rev. 55: 73-106, 2001.

Gentry A., Dodson C.: Diversity and biogeography of neotropical vascular epiphytes. - Ann. Mo. Bot. Gard. 74: 205-233, 1987.

Goh C., Kluge M.: Gas exchange and water relation in epiphytic orchids. - In: Lüttge U. (ed.): Vascular Plants as Epiphytes: Evolution and Ecophysiology. Pp. 139-166. Springer, BerlinHeidelberg-New York 1989.

Goldsmith G.R., Muñoz-Villers L.E., Holwerda F. et al.: Stable isotopes reveal linkages among ecohydrological processes in a seasonally dry tropical montane cloud forest. Ecohydrology 5: 779-790, 2012.

González-Medrano F.: [The vegetation, floristic diversity and endemisms.] - In: Sánchez-Ramos G., Reyes-Castillo P., Dirzo R. (ed.): [Natural History of the El Cielo Biosphere Reserve, Tamaulipas, Mexico.] Pp. 88-105. Autonomous University of Tamaulipas, Mexico 2005. [In Spanish]

Gradstein S.R.: The lowland cloud forest of French Guiana A liverwort hotspot. - Cryptogam. Bryol. 27: 141-152, 2006.

Griffiths H., Lüttge U., Stimmel K.H. et al.: Comparative ecophysiology of CAM and $\mathrm{C}_{3}$ bromeliads. III. Environmental influences on $\mathrm{CO}_{2}$ assimilation and transpiration. - Plant Cell Environ. 9: 385-393, 1986.

Griffiths H., Maxwell K.: In memory of C.S. Pittendrigh: Does exposure in forest relate to photoprotective strategies in epiphytic bromeliads? - Funct. Ecol. 13: 15-23, 1999. 
Griffiths H., Smith A.: Photosynthetic pathways in the Bromeliaceae of Trinidad: Relations between life-forms, habitat preference and the occurrence of CAM.-Oecologia 60: 176-184, 1983

Griffiths H., Smith J.A.C., Lüttge U. et al.: Ecophysiology of xerophytic and halophytic vegetation of a coastal alluvial plain in northern Venezuela. IV. Tillandsia flexuosa Sw. and Schomburgkia humboldtiana Reichb., epiphytic CAM plants.New Phytol. 111: 273-282, 1989.

Grubb P.J., Lee W.G., Kollmann J., Wilson J.B.: Interaction of irradiance and soil nutrient supply on growth of seedlings of ten European tall-shrub species and Fagus sylvatica. J. Ecol. 84: 827-840, 1996.

Hágsater E., Soto A.M.G., Salazar C.G.A. et al.: [The Orchids of Mexico.] Pp. 304. Chinoín Institute, Mexico 2005. [In Spanish]

Jones H.G.: Plants and Microclimate: A Quantitative Approach to Environmental Plant Physiology. Pp. 428. Cambridge University Press, Cambridge 1992.

Juvik J.O., Ekern P.C.: A climatology of mountain fog on Mauna Loa, Hawaii Island. Pp. 63. Water Resources Research Center, University of Hawaii, Honolulu 1978.

Kitao M., Lei T.T., Koike T.: Susceptibility to photoinhibition of three deciduous broadleaf tree species with different successional traits raised under various light regimes. - Plant Cell Environ. 23: 81-89, 2000.

Kitao M., Lei T.T., Koike T.: Temperature response and photoinhibition investigated by chlorophyll fluorescence measurements for four distinct species of dipterocarp trees. Physiol. Plantarum 109: 284-290, 2001.

Kreft H., Köster N., Küper W. et al.: Diversity and biogeography of vascular epiphytes in Western Amazonia, Yasuní, Ecuador. J. Biogeogr. 31: 1463-1476, 2004.

Kull T., Hutchings M.J.: A comparative analysis of decline in the distribution ranges of orchid species in Estonia and the United Kingdom. - Biol. Conserv. 129: 31-39, 2006.

Lambers H.F., Chapin III S., Pons T.L.: Plant Physiological Ecology. Pp. 540. Springer, New York 1998

Laube S., Zotz G.: Which abiotic factors limit vegetative growth in a vascular epiphyte? - Funct. Ecol. 17: 598-604, 2003.

Lie M.H., Arup U., Grytnes J.A., Ohlson M.: The importance of host tree age, size and growth rate as determinants of epiphytic lichen diversity in boreal spruce forests. - Biodivers. Conserv. 18: 3579-3596, 2009.

Lin M.J., Hsu B.D.: Photosynthetic plasticity of Phalaenopsis in response to different light environments. -J. Plant Physiol. 161: 1259-1268, 2004.

Loeschen V.S., Martin C.E., Smith M., Eder S.L.: Leaf anatomy and $\mathrm{CO}_{2}$ recycling during Crassulacean acid metabolism in twelve epiphytic species of Tillandsia (Bromeliaceae). - Int. J. Plant Sci. 154: 100-106, 1993.

Luna-Vega I., Alcántara-Ayala O., Contreras-Medina R., Ponce Vargas A.: Biogeography, current knowledge and conservation threatened vascular plants characteristic of Mexican temperate forests. - Biodivers. Conserv. 15: 3773-3799, 2006.

Luna-Vega I., Alcántara-Ayala O., Morrone J.J., Espinosa D.: Track analysis and conservation priorities in the cloud forests of Hidalgo, Mexico. - Divers. Distrib. 6: 137-143, 2000.

Lüttge U.: Carbon dioxide and water demand: Crassulacean acid metabolism (CAM), a versatile ecological adaptation exemplifying the need for integration in ecological work. New Phytol. 106: 593-629, 1987.

Lüttge U.: $\mathrm{CO}_{2}$-concentrating: Consequences in crassulacean acid metabolism. - J. Exp. Bot. 53: 2131-2142, 2002.

Martin C.E.: Physiological ecology of the Bromeliaceae. - Bot. Rev. 60: 1-82, 1994.
Martin C.E., Adams III W.W.: Crassulacean acid metabolism $\mathrm{CO}_{2}$-recycling, and tissue desiccation in the Mexican epiphyte Tillandsia schiedeana Steud (Bromeliaceae). - Photosynth. Res. 11: 237-244, 1987.

Martin C.E., Lin T.C., Lin K.C. et al.: Causes and consequences of high osmotic potentials in epiphytic higher plants. - J. Plant Physiol. 161: 1119-1124, 2004.

Maxwell K., Johnson G.N.: Chlorophyll fluorescence a practical guide. - J. Exp. Bot. 51: 659-668, 2000.

Moreira A.S.F.P., Lemos-Filho J.P., Zotz G. et al.: Anatomy and photosynthetic parameters of roots and leaves of two shade-adapted orchids, Dichaea cogniauxiana Shltr. and Epidendrum secundum Jacq. - Flora 204: 604-611, 2009.

Mulkey S.S., Pearcy R.W.: Interactions between acclimation and photoinhibition of photosynthesis of a tropical forest understory herb, Alocasia macrorrhiza, during simulated canopy gap formation. - Funct. Ecol. 6: 719-729, 1992.

Nadkarni N.M.: Epiphyte biomass and nutrient capital of a neotropical elfin forest. - Biotropica 16: 249-256, 1984.

Nadkarni N., Solano R.: Potential effects of climate change on canopy communities in a tropical cloud forest: An experimental approach. - Oecologia 131: 580-586, 2002.

Nash N., Barrett R.L., Oakely H.F. et al.: Role of orchid societies and growers in conservation. - In: Dixon K.W., Kell S.P., Barrett R.L., Cribb P.J. (ed.): Orchid Conservation. Pp. 313328. Natural History Publications, Kota Kinabalu 2003.

Niinemets U.: Photosynthesis and resource distribution through plant canopies. - Plant Cell Environ. 30: 1052-1071, 2007.

Nowak E.J., Martin C.E.: Physiological and anatomical responses to water deficits in the CAM epiphyte Tillandsia ionantha (Bromeliaceae). - Int. J. Plant Sci. 158: 818-826, 1997.

Osmond C.B.: What is photoinhibition? Some insights from comparisons of sun and shade plants. - In: Baker N.R., Bowyer J.R. (ed.): Photoinhibition of Photosynthesis: From Molecular Mechanisms to the Field. Pp. 1-24. Bios Scientific Publishers, Oxford 1994.

Phelps J., Webb E.W.: 'Invisible' wildlife trades: Southeast Asia's undocumented illegal trade in wild ornamental plants. - Biol. Conserv. 186: 296-305, 2015.

Pires M.V., Furtado de Almeida A.A., Abreu P., da Costa Silva D.: Does shading explain variation in morphophysiological traits of tropical epiphytic orchids grown in artificial conditions? Acta Physiol. Plant. 34: 2155-2164, 2012.

Pridgeon A.M.: Shoot anatomy of two additional species of Dresslerella (Orchidaceae). - Selbyana 5: 274-278, 1981.

Pridgeon A.M., Cribb P.J., Chase M.W. et al.: Genera Orchidacearum. Volume 5. Pp. 664. Oxford University Press, Oxford 2009.

Ray H.A., Stuhl C.J., Gillett-Kaufman J.L.: Floral fragrance analysis of Prosthechea cochleata (Orchidaceae), an endangered native, epiphytic orchid in Florida. - Plant Signal. Behav. 13: e1422461, 2018.

Reyes-García C., Griffiths H., Rincón E., Huante P.: Niche differentiation in tank and atmospheric epiphytic bromeliads of a seasonally dry forest. - Biotropica 40: 168-175, 2008.

Reyes-García C., Griffiths H.: Ecophysiological studies of perennials of the Bromeliaceae family in a dry forest: Strategies for survival. - In: de la Barrera E., Smith W.K. (ed.): Perspectives in Biophysical Plant Ecophysiology. A Tribute to Park S. Nobel. Pp. 121-151. National Autonomous University of Mexico, Mexico 2009.

Reyes-García C., Mejia-Chang M., Griffiths H.: High but not dry: Diverse epiphytic bromeliad adaptations to exposure within a seasonally dry tropical forest community. - New Phytol. 193: 745-754, 2012.

Rosado-Calderón A.T., Tamayo-Chim M.I., de la Barrera E. et al.: 
High resilience to extreme climatic changes in the CAM epiphyte Tillandsia utriculata L. (Bromeliaceae). - Physiol. Plantarum: https://doi.org/10.1111/ppl.12805, 2018. (In print)

Rzedowski J.: [Vegetation of Mexico.] Pp. 492. Ed. Limusa, Mexico 1978. [In Spanish]

Rzedowski J.: [Preliminary analysis of the vascular flora of the Mexican montane cloud forests.] - Acta Bot. Mex. 35: 25-44, 1996. [In Spanish]

Salehi-Lisar S.Y., Bakhshayeshan-Agdam H.: Drought stress in plants: Causes, consequences, and tolerance. - In: Hossain M.A., Wani S.H., Bhattacharjee S. et al. (ed.): Drought Stress Tolerance in Plants. Vol. 1. Physiology and Biochemistry. Pp. 1-16. Springer, Cham 2016.

Sánchez-González L.A., Morrone J.J., Navarro-Sigüenza A.G.: Distributional patterns of the Neotropical montane forest avifaunas. - Biol. J. Linn. Soc. 94: 175-194, 2008.

Sánchez-Ramos G., Dirzo R.: [The tropical montane cloud forest: A threatened priority ecosystem.] - In: Gual-Díaz M., Rendón-Correa A. (ed.): [Tropical Montane Cloud Forest of Mexico: Diversity, Ecology and Management.] Pp. 109-139. CONABIO, Mexico 2014. [In Spanish]

Sanders G.J., Arndt S.K.: Osmotic adjustment under drought conditions. - In: Ricardo A. (ed.): Plant Responses to Drought Stress. Pp. 199-229. Springer, Berlin 2012.

SEMARNAT: [Ministry of Environment and Natural Resources. Official Mexican law NOM-059-SEMARNAT-2010, Environmental protection. Mexican native species of wild flora and fauna. Risk categories and specifications for inclusion, exclusion or change. List of species at risk.] Pp. 78. Official Journal of the Federation, Mexico 2010. [In Spanish]

Silvera K., Santiago L., Cushman J.C., Winter K.: Crassulacean acid metabolism and epiphytism linked to adaptive radiations in the Orchidaceae. - Plant Physiol. 149: 1838-1847, 2009.

Sinclair R.: Water relations of tropical epiphytes: I. Relationships between stomatal resistance, relative water content and the components of water potential. - J. Exp. Bot. 34: 1652-1663, 1983a.

Sinclair R.: Water relations of tropical epiphytes: II. Performance during droughting. - J. Exp. Bot. 34: 1664-1675, 1983 b.

Smith J.A.C.: Epiphytic bromeliads. - In: Lüttge U. (ed.): Vascular Plants as Epiphytes: Evolution and Ecophysiology. Pp 109-138. Springer-Verlag, Berlin 1989.

Soto-Arenas M.A., Solano-Gómez A.R.: [Stanhopea tigrina datasheet.] - In: Soto-Arenas M.A. (ed.): [Updated Information on Orchid Species of the PROYNOM-059-ECOL-2000.] Pp. 1-9. Chinoín Institute A.C., Herbarium of the Mexican Association of Orchideology, A.C. Databases SNIBCONABIO, Mexico 2007. [In Spanish]

Stadtmüller T.: Cloud Forests in the Humid Tropics. A Bibliographic Review. Pp. 82. United Nations University Press, Tokyo 1987.

Stancato G.C., Mazzafera P., Buckeridge M.S.: Effect of a drought period on the mobilization of non-structural carbohydrates, photosynthetic efficiency and water status in an epiphytic orchid. - Plant Physiol. Bioch. 39: 1009-1016, 2001.

Stiles K.C., Martin C.E.: Effects of drought stress on $\mathrm{CO}_{2}$ exchange and water relations in the CAM epiphyte Tillandsia utriculata (Bromeliaceae). - J. Plant Physiol. 149: 721-728, 1996.

Sultan S.E.: Phenotypic plasticity in plants: A case study in ecological development. - Evol. Dev. 5: 25-33, 2003.

Tay S., He J., Yam T.W.: Photosynthetic light utilization efficiency, water relations and leaf growth of $\mathrm{C}_{3}$ and CAM tropical orchids under natural conditions. - Am. J. Plant Sci. 6: 29-49, 2015.

Tognetti R., Longobucco A., Miglietta F., Raschi A.: Transpiration and stomatal behavior of Quercus ilex plants during summer in a Mediterranean carbon dioxide spring. - Plant Cell Environ. 21: 613-622, 1998a.

Tognetti R., Minotta G., Pinzauti S. et al.: Acclimation to changing light conditions of long-term shade-grown beech (Fagus sylvatica $\mathrm{L}$ ) seedlings of different geographic origins. Trees 12: 326-333, 1998b.

Trenberth K.E., Fasullo J.T., Branstator G., Phillips A.S.: Seasonal aspects of the recent pause in surface warming. Nat. Clim. Change 4: 911-916, 2014.

Walters R.G.: Towards an understanding of photosynthetic acclimation. - J. Exp. Bot. 56: 435-447, 2005.

Wolf J.H.D., Flamenco A.: Patterns in species richness and distribution of vascular epiphytes in Chiapas, México. J. Biogeogr. 30: 1689-1707, 2003.

Wolf J.H.D., Flamenco A.: Vascular epiphytes and their potential as a conservation tool in pine-oak forests of Chiapas, México. - In: Kappelle M. (ed.): Ecology and Conservation of Neotropical Montane Oak Forests. Pp. 375-391. Springer Verlag, Berlin 2006.

Yang Y., Donohue J.R., McVicar T.R.: Global estimation of effective plant rooting depth: Implications for hydrological modelling. - Water Resour. Res. 52: 8260-8276, 2016.

Zhang S.B., Hu H., Xu K. et al.: Flexible and reversible responses to different irradiance levels during photosynthetic acclimation of Cypripedium guttatum. - J. Plant Physiol. 164: 611-620, 2007.

Zhang S.R., Ma K.P., Chen L.Z.: Response of photosynthetic plasticity of Paeonia suffruticosa to changed light environments. - Environ. Exp. Bot. 49: 121-133, 2003.

Zheng X.N., Wen Z.Q., Pan R.C., Hew C.S.: Response of Cymidium sinense to drought stress. - J. Hortic. Sci. 67: 295299, 1992.

Zotz G., Andrade J.L.: Water relations of two co-occurring epiphytic bromeliads. - J. Plant Physiol. 152: 545-554, 1998.

Zotz G., Asshoff R.: Growth in epiphytic bromeliads: Response to the relative supply of phosphorus and nitrogen. - Plant Biol. 12: 108-113, 2010.

Zotz G., Hietz P.: The physiological ecology of vascular epiphytes: Current knowledge, open questions. - J. Exp. Bot. 52: 2067-2078, 2001.

(C) The authors. This is an open access article distributed under the terms of the Creative Commons BY-NC-ND Licence. 